\title{
中外科学家共聚 研讨生物物理领域研究进展及成果转化
}

2018年8月24 27日, 由中国生物物理学会主办、四川 省医学科学院四川省人民医院协办的第十六次中国暨国 际生物物理大会在成都市召开. 1100余名来自美国、英国、 日本、加拿大、奥地利、以色列、新西兰、新加坡等国家 及港澳台地区的学者, 以及国内各高校、研究机构及企业 的研究人员参加了此次大会. 与会者围绕“生物物理与人 类健康”这一主题, 进行了充分的交流与讨论.

\section{1 研讨生物物理领域最新研究进展, 增进 国内和国际间交流与合作}

正如大会主席中国生物物理学会理事长徐涛院士在开 幕辞中所说, 传统生物物理学到现代生物物理学的发展, 为 中国生物物理学会的发展带来了新的机遇, 国际交流日益 增多. 与会者通过大会平台, 可以获取生物物理及相关领 域的最新研究进展和成果, 增进彼此间的科研交流与合作.

本次大会设立分子生物物理学、神经生物物理学、膜 生物学、代谢生物学等 22 个学术专题分会场及墙报展示, 通过240场专题报告、350余篇摘要, 报告人向参会代表分 享、交流了他们的最新研究进展, 并针对相关科学问题与 参会者进行了热烈的讨论和深人的交流.

美国St. Jude儿童医院Paul Taylor教授、美国Columbia 大学Wayne Hendrickson教授、香港科技大学张明杰院士、 复旦大学徐彦辉教授、中国科学院上海生物化学与细胞生 物学研究所陈玲玲研究员、北京大学周专教授、中国科学 院生物物理研究所李国红研究员受邀担任大会特邀报告 人; 中国科技大学施蕴渝院士受邀担任新技术前沿特邀报 告人. 8 个主题报告涉及结构生物学、蛋白质相转变、神经 生物物理学、核酸生物学等前沿领域, 展示了生物物理学 及相关学科最新的研究动态与科学发现, 并充分体现了生 物物理学的学科融合、交叉与前瞻特色.

大会还特别注重国际化, 通过与以色列生理药理学会
(Israeli Society of Physiology and Pharmacology)、奥地利生 物物理学会(Austrian Biophysical Society)联合举办的双边 论坛, 与会者在国际间的学术交流与合作方面都收获 颇丰.

\section{2 举办产业化论坛，助力生物物理领域科 技成果转化}

促进科技成果转化是实施创新驱动发展战略的重要任 务, 但目前我国科技成果产业化中存在着不少困难, 转化 成功率远不如一些发达国家. 因此大会期间举办了产业化 论坛, 邀请了在产业化方面有丰富经验的梁伟研究员担任 论坛主席, 汇聚了多位国内顶尖科研机构及公司的资深科 学家和企业家, 通过报告人的演讲和成功案例, 使与会科 学家对前沿科学研究成果如何实现产业化有更为深刻了 解与认识, 为助力生物物理领域科研成果与产业发展之间 更好地对接、使科学家的科技成果在更短时间内更高效地 进人产业化道路发挥了积极作用.

本次大会还特别针对青年科学家和女科学家设立了青 年科研生涯讲座及“女性与生物物理之美”论坛, 北京大学 程和平院士与参会代表分享了他的科研道路, 对青年科学 家提出了殷切的期望与中肯的建议; 中国科学院上海药物 研究所吴蓓丽研究员与参会代表分享了她在学习、科研和 生活中积累的经验与体会; 中华女子学院党委书记李明舜 教授从法学和女性学的角度, 阐释了女性如何坚持人格尊 严与身心健康. 这一系列精彩报告为事业起始期的青年科 学家提供了可以参考借鉴的宝贵经验.

本次大会不仅是生物物理学领域的重要学术盛会, 更 是我国在生命科学、化学、物理学等相关学科持续跨越发 展、不断取得突破的见证. 本次大会的成功举行将大大促 进生物物理学的学科发展, 并为人类健康事业的发展作出 更大的贡献.
卫涛涛

中国科学院生物物理研究所, 生物大分子国家重点实验室, 北京 100101 